\title{
Helder e Llansol: a espacialização da linguagem ${ }^{\prime}$
}

\author{
Luanna Belmont \\ (Universidade Federal Fluminense)
}

\section{RESUMO}

As poéticas de Herberto Helder e Maria Gabriela Llansol são, hoje, na Literatura Portuguesa, as que mais radicalmente encarnam uma concepção do mundo e, por extensão, da literatura atravessada pela tradição surrealista e por uma certa orientação mística que redefinem a experiência do sujeito com a linguagem. Sua poética assenta-se sobre (1) uma conexão profunda entre os processos de leitura e escrita, (2) uma visão utópica do texto como lugar de encontro da diferença e de reverberação dos afetos, e (3) uma compreensão do sentido como metamorfose. O presente trabalho pretende flagrar essa performance da linguagem no fluxo do texto, bem como a espacialização das relações do sujeito com a paisagem.

PALAVRAS-CHAVE: Maria Gabriela Llansol, Herberto Helder, Paisagem.

\section{ABSTRACT}

Herberto Helder and Maria Gabriela Llansol poetics are, today, in the Portuguese Literature, those which most radically embody a world and, by extention, a literature conception crossed by the surrealist tradition and by a certain mystical orientation which redefines the subject experience with language. Their poetics lay down on (1) a deep connection between the reading and the writing processes, (2) an utopic vision of the text as a meeting place for difference and of affect reverberation, and (3) a comprehension of meaning as metamorphosis. The present paper intends to catch this language performance along the text flow, as well as the spacialization of the relationship between the subject and the view.

KEYWORDS: Maria Gabriela Llansol, Herberto Helder, View. 


\section{1.}

Joaquim Manuel Magalhães, poeta e crítico português do nosso tempo, preocupado com as consequências da massificação literária para a produção e a recepção da poesia a partir da segunda metade do século XX em Portugal, opina com firmeza sobre a importância da ideologia que um texto carrega. Para ele, a carga de pensamento é necessária tão somente para fazer disparar a estrutura do verbo. O cristianismo, o marxismo ou a mitologia clássica, portanto, que orientam tantas obras, não valeriam por si sós, como princípios potencialmente divergentes de outros princípios, senão como deflagradores.

O que Magalhães defende, e que nos interessa diretamente aqui, é, em outros termos, o valor instrumental da ideia no texto, para o texto. $\mathrm{O}$ que não significa dizer secundário, mas deformador, transformador, como o amor camoniano, capaz de transformar o amador na coisa amada em virtude do muito imaginar. Ou como os martelos de Herberto Helder, em poema-diálogo com o famoso soneto de Camões, que imprimem na mulher amada uma violência também transformadora, tornando-a de amada em amadora. Neste último caso, o amador é ele mesmo o martelo que "bate, bate, bate", e a transforma, porque "o amador é tudo, e a coisa amada / É uma cortina / Onde o vento do amador bate no alto da janela" (HELDER, 2004, p. 14). Mas o poeta não é vento, é martelo. O poeta é seu próprio instrumento, confunde-se com suas próprias ideias, que deverão ser seu instrumento para alterar o texto na sua constituição última. $\mathrm{O}$ valor da ideia estaria, portanto, em sua força de materialização, em sua capacidade de insuflar e conduzir um corpo de linguagem que, ao se concretizar, concretiza também os valores que o norteiam.

Mesmo que se espere da literatura que esteja comprometida politicamente, ela só é, digamos, eficaz, quando o corpo textual criado pelo sujeito segue as instruções estéticas mais sutis afinadas à ética por ele adotada. Não é possível à literatura, portanto, como o é a outras propostas textuais, falar de algo, simplesmente, senão trazê-lo para dentro de seu corpo criado para ser a própria ideia, tornar-se ele mesmo um lugar de realização dessa ideia, sua prova viva porque vivo é o texto sempre -, a prova de que a ideia é ou pode ser, em alguma dimensão, real. E a primeira realidade garantida ao pensamento é a realidade do texto em que ele se infunde, com que se confunde.

Esse corpo, mais do que representá-las, finalmente, encarnará certas ideias, e não outras, na sua estrutura, na sua forma mais original e fiel, e, assim, em vez de falar delas a outros, vai demonstrá-las na própria performance do texto, tornálas vivas aos sentidos do leitor, superando o mero discurso de reprodução de uma retórica, na medida em que vai abrigando cada valor na sua própria carne de signo. A poesia não semelha ou refere-se a ideologia alguma, não carrega como uma fé conteúdos alheios, e sim é carregada por eles, absorve-os de um lugar exterior para o seu lugar de linguagem, interiorizando-os de modo que se confundam com seu próprio “jogo de invenção verbal” (MAGALHÃES, 1981, p. 124).

Interessa-nos, então, como ia dizendo, essa noção fundamental da poesia como autonomia cosmogônica, da literatura como um empreendimento inseparável da vida, que se compromete com ela da maneira mais visceral, ou sacrificial, diria, pois que a linguagem sacrifica o próprio corpo na expressão sem garantias, embora tão livre e tão cuidada. Arrisca-se, na criação, ao descobrimento dos contrários, do indizível e do ilegível, e a começar tudo outra vez. Entrega-se a linguagem à decifração como paisagem dinâmica que imita a metamorfose do mundo, a denunciar que todo discurso é um enigma, por mais que não o pareça. 
Falo de uma estética que emerge, antes de mais nada, de uma ética do sujeito perante o mundo, de sua cosmovisão, e que se converterá em ato concreto, na ação transformadora desse sujeito sobre o mundo.

O texto literário é, portanto, um lugar de ação real, ou de ação sobre o real, ou, simplesmente, um lugar real, para além do enredo circunscrito de uma narrativa ou das analogias de um poema, mas que conta com eles para agir sobre o mundo. Um lugar a um tempo paralelo e coincidente com a realidade; utópico e verossímil; raro e cotidiano; mágico e banal; isolado e aberto; particular e comum. E, se o texto literário é esse lugar estranho, poderoso, criado e criador, um onde que se realiza como espaço de linguagem, de observação, de ativação dos sentidos, de aprendizado, de encontros e de ação, é preciso entender os seus mecanismos, o seu projeto de transformação, os seus desejos. Tudo isso corresponde, no fundo, à ética ou à concepção de mundo que o engendra.

Mas não a descobriremos a priori, antes, como se ela fosse uma palavra de ordem vinda de fora para dentro do texto literário. Nele, as ideologias se constroem e se questionam, assim como a própria forma. Bem de acordo com o que colocamos até aqui, só será possível desvendar uma ética se nos dispusermos, simultaneamente, a decifrar ou a ler a escrita que a comporta. Sem garantias, repito, pois a recusa do texto, seu fechamento para as lógicas mais fáceis de leitura, faz parte do jogo. Ética e estética juntas constituirão, então, mais do que um projeto individual de escrita e autoria: um caminho de leitura manifesta do mundo, leitura escrita, leitura-escrita, fixação provisória convidando ao desvendamento.

Indissociáveis, ética e estética, além disso, abrirão no texto, paralelamente à constituição do estilo ou do tema específico que o move, oportunidades para pensar a íntima relação entre a realização desta escrita e a manifestação de uma subjetividade, isto é, entre a criação literária e o posicionamento do sujeito no mundo. Mais especificamente, para pensar o papel da literatura nessa relação. Os lugares que esse sujeito reserva no texto para cada ser e objeto, as relações que estabelece entre eles e como se coloca diante deste cenário dirão muito não apenas sobre sua concepção de mundo, mas sobre sua concepção da literatura. Por isso, cada texto que assume organicamente, na sua estrutura, a sua verdade ética, promove sempre, também, um espaço para a reflexão metaliterária, sobre o que deve significar, para esse sujeito, escrever um texto, fazer literatura. É na esteira destas considerações que desejo conduzir a proposta deste artigo: identificar aproximações entre as poéticas dos portugueses Herberto Helder e Maria Gabriela Llansol, revelando os bastidores da minha leitura, ou melhor, como ler Helder ajudou-me imensamente a entender Llansol, ou a "desdobrar" ainda mais minha leitura de sua obra.

\section{2.}

Tornaram-se evidentes demais para mim as semelhanças entre essas duas escritas que chamo, aqui, de caligrafias extremas, expressão que tomei emprestada ao Helder. A começar, justamente, pela concepção, assumida por ambos como uma das chaves de leitura de suas respectivas obras, de que se trata, cada qual, de um prolongamento textual ininterrupto (a "textualidade" llansoliana e o "poema contínuo" helderiano), ou seja, de escritas que perfazem um drama contínuo a cada ato, ou a cada livro, como personagens de si mesmas.

Assim, o primeiro elo entre Helder e Llansol é o fato de que suas escritas constituem um espaço, compartilhado com o leitor, para a evolução cênica da própria linguagem, e por isso um lugar de muitos encontros e retornos, de figuras que vão e voltam, de seres e objetos que trocam de nome e de papel. Escritas que 
são verdadeiras paisagens subjetivas - mas toda paisagem, nos dirá Collot, é uma construção da subjetividade (COLLOT, 1995) - acolhedoras de todas as coisas que a linguagem pode tocar, da diversidade, tornando-as, às vezes, mais reais, outras vezes mais abstratas à medida que se deslocam no texto. Vale a pena, aqui, antecipar um poema de Herberto Helder em que fica bastante visível esta "coreografia de signos" que movimenta o texto. Ela torna-o uma paisagem viva que não é nem a projeção verbal de uma realidade concreta, embora alimente-se dela, nem uma ficção autônoma, apesar de também se alimentar, com orgulho, de sua condição de linguagem. Vejamos:

\section{As Musas Cegas IV}

Mulher, casa e gato.

Uma pedra na cabeça da mulher; e na cabeça

da casa, uma luz violenta.

Anda um peixe comprido pela cabeça do gato.

A mulher senta-se no tempo e na minha melancolia pensa-a, enquanto

o gato imagina a elevada casa.

Eternamente a mulher da mão passa a mão

pelo gato abstracto,

e a casa e o homem que vou ser

são minuto a minuto mais concretos.

A pedra cai na cabeça do gato e o peixe

gira e pára no sorriso

da mulher da luz. Dentro da casa,

o movimento obscuro destas coisas que não encontram palavras.

Eu próprio caio na mulher, o gato

adormece na palavra, e a mulher toma

a palavra do gato no regaço.

Eu olho, e a mulher é a palavra.

Palavra abstracta que arrefeceu no gato

e agora aquece na carne

concreta da mulher.

A luz ilumina a pedra que está

na cabeça da casa, e o peixe corre cheio

de originalidade por dentro da palavra.

Se toco a mulher toco o gato, e é apaixonante.

Se toco (e é apaixonante)

a mulher, toco a pedra. Toco o gato e a pedra.

Toco a luz, ou a casa, ou o peixe, ou a palavra.

Toco a palavra apaixonante, se toco a mulher com seu gato, pedra, peixe, luz e casa.

A mulher da palavra. A Palavra.

Deito-me e amo a mulher. E amo

o amor na mulher. E na palavra, o amor.

Amo, com o amor do amor, 
não só a palavra mas

cada coisa que invade cada coisa

que invade a palavra.

E penso que sou total no minuto

em que a mulher eternamente

passa a mão da mulher no gato

dentro da casa.

No mundo tão concreto. (HELDER, 2004, p. 84-85)

O poema propõe (provoca) um desencontro entre coisas e palavras, de modo que seu reencontro possa se realizar em outras bases que não o sistema convencional da língua social, mas na metáfora mágica da linguagem poética. $O$ sistema tradicional segundo o qual a palavra é a coisa e a coisa é a palavra, cuja magia, por sua vez, por hábito do uso, desprezamos, parece bastante mais interessante quando podemos fazer o caminho inverso. De repente, graças ao poema, nada é mais o que era antes, nem está mais no mesmo lugar, e, ao mesmo tempo que nos agarramos às correntes que prendem cada coisa a sua palavra, elas parecem enrolar-se umas às outras, arrastando-se, e a nós junto, involuntariamente, para onde não esperamos. O leitor intuirá, justamente, um desejo profundo de transpor essa fronteira que separa a realidade dos objetos e a realidade dos signos, igualados no poema, no mesmo vazio recíproco e desorientado que só a leitura, ao acompanhar os deslocamentos propostos, poderá transformar em plenitude semântica.

Assim, a palavra é todas as coisas, e cada coisa é outra coisa e palavra. O mundo concreto é o mundo que pode ser tocado pelo corpo e pela palavra, que é a extensão imaginária do corpo, e, ao mesmo tempo, tão concreta quanto ele. Por isso, tocar torna-se um ato não apenas físico, mas metafísico, na medida em que sempre remete a um além, a algo que não é aquilo que é tocado: "Se toco a mulher toco o gato, e é apaixonante. / Se toco (e é apaixonante) / a mulher, toco a pedra. Toco o gato e a pedra. / Toco a luz, ou a casa, ou o peixe, ou a palavra." E cada coisa tocada é uma remissão imediata a outra, conforme nos ensina o mecanismo metafórico da linguagem, trazido à evidência pelo poeta.

Por outro lado, ao flagrar os seres e as coisas como lugares de passagem, pontos de partida para outros seres e coisas, o poema reduz a concretude individual de cada coisa à concretude remissora da palavra, condensação provisória que o próprio toque, ao confirmar, desfaz. Prevalece, então, uma sensação constante de movimento, de fluidez, e, por que não?, de velocidade, em que a visão sequencial dos elementos da paisagem, como a de um sujeito que olha pela janela de um trem ou automóvel, é gradualmente substituída por uma visão em concomitância, onde todos os elementos aparecem ao mesmo tempo, como se o pensamento, incapaz de acompanhar o ritmo frenético dos deslocamentos e remissões, mas desejando-o desesperadamente, transformasse a aceleração em simultaneidade, numa grande e única paisagem estática e, no entanto, convulsamente móvel. Esta sensação nos é transmitida no poema "As Musas Cegas IV", citado acima, quando, na segunda metade da terceira estrofe, o poeta, por duas vezes, estrutura uma sequência de elementos - "Toco a luz, ou a casa, ou o peixe, ou a palavra." (grifos meus) - substituindo, da segunda vez, a conjunção "ou”, que organizou a primeira estrutura em termos de alternância, pela ausência de conjunções, pela preposição "com” e, finalmente, pela conjunção "e", sugerindo uma justaposição contínua 
e/ou um espalhamento desordenado desses elementos na paisagem: "toco a mulher / com seu gato, pedra, peixe, luz e casa."

Neste ponto, vale a pena aproveitar o comentário de Pedro Eiras a respeito do texto "(a paisagem é um ponto de vista)", de Herberto Helder, publicado no seu livro Photomaton \& Vox, versão de 1979, em que o poeta propõe uma analogia entre a visão panorâmica e vertical que se tem de um helicóptero e a investigação, ao mesmo tempo ágil, profunda e caótica, em todos os sentidos e direções, que a poesia pretende fazer de seus objetos eleitos, e de si mesma. Ao observar a oposição básica entre a contemplação horizontal da natureza e o olhar vertical da poesia, ou seja, entre o passeio de bicicleta e o vôo de helicóptero, criada pelo texto de Helder, Eiras acaba por tocar num aspecto de sua escrita que nos importa aqui: o gosto pelo caos, pelo deslocamento no tempo e no espaço, pelo abandono dos pontos de vista usuais, pela altura que, aqui, é a versão complementar do mergulho, enfim, pela rapidez com que os corpos e, entre eles, as palavras alteram sua posição no espaço, o que a Física chama tradicionalmente de velocidade, e Helder, de poesia. Comenta Eiras:

Em Herberto Helder, não só a panorâmica permitida pelo helicóptero é a única que atinge a essência do objecto (poético) perscrutado, mas ainda a visão rasa do mundo dos viajantes em mala-posta é condenada. A velocidade do pensamento e a visão simultânea do múltiplo diacrônico em «(a paisagem é um ponto de vista)», com a sua recusa do tratado extenso e da cronologia linear, são já um manifesto e um exemplo de como perscrutar a poesia. Ao escrever desta altitude, Helder propõe que viagem, observação e leitura sejam uma e a mesma actividade. (EIRAS, 2005, p. 153)

Este mundo apaixonante, porque palpável, e que se desmancha quando tocado, é o ponto de partida para a observação da correspondência entre todas as coisas que vão, aos poucos, confundindo-se e tornando-se mais abstratas quanto mais concretas, tocadas pela sensibilidade do poeta. No sentido inverso, a palavra ganha corpo de objeto ou ser, e torna-se concreta, como se recebesse a substância das coisas, a tomasse para si, ao mesmo tempo que as esvazia de sua concretude ao nomeá-las. Cada coisa (mulher, casa, gato, pedra, peixe, palavra) é no mundo, e também na cabeça, no corpo do sujeito que as observa (pensamento, desejo, imaginação), e no tempo, que é eterno mas se move.

Pensamento e tempo, portanto, se confundem, deslocando todas as coisas ("anda um peixe", "a mulher senta-se", "a mulher da mão passa a mão/pelo gato abstracto", "a pedra cai", "o peixe gira”) no jogo da observação, promovendo o "movimento obscuro destas coisas", perdidas, dançantes no grande lugar, perdidas até das palavras que as fazem ser, e por isso deixam de ser sempre as mesmas coisas nos mesmos lugares, como se escorregassem para fora de si mesmas e ocupassem os espaços (palavras?) umas das outras: "Eu próprio caio na mulher, o gato / adormece na palavra e a mulher toma / a palavra do gato no regaço.” E, de repente, cada coisa não é mais, e há grande paixão nisso. Tocar cada uma é tocar a outra, e a palavra subjaz em todas, morre em uma para renascer em outra, e cada coisa perde seu status, seu corpo, sua substância, seu lugar original, até restar apenas, concreta sobre todas elas, a Palavra, tocada (percebida e movida) pelo poeta. 
Observe-se que todo este movimento acontece a partir de uma situação inicial de aparente harmonia apresentada nos primeiros versos do poema, em que o olhar do leitor é orientado em torno de três elementos centrais e simplórios mulher, casa e gato - que passam a interagir com outros elementos da cena cabeça, mão, luz, peixe -, aparentemente periféricos no enredo que apenas começa a se formar. Cada coisa, neste momento original, parece ocupar o seu lugar previsível na paisagem, pois o leitor ainda não se desarmou das convenções, e as sugestões do texto ainda são lidas dentro de seus limites: "uma pedra na cabeça da mulher" (terá caído a pedra na cabeça da mulher?, terá a mulher pensado na pedra?), "na cabeça / da casa, uma luz violenta" (do alto da casa viria uma luz violenta?), "anda um peixe comprido pela cabeça do gato" (certamente, o gato imagina um peixe que muito deseja comer, ou, ao vê-lo à distância, passa a desejálo).

Tal expectativa de leitura correspondida pelo desejo do leitor - que deseja a coerência como o gato deseja o peixe -, em que cada ser e objeto está onde deveria estar e faz o que deveria fazer, coincide com uma percepção forte de concretude por parte do eu lírico, conforme apontamos antes. Este termina a primeira estrofe com a certeza de que aquilo que vê agora, e também o seu futuro - "o homem que vou ser" -, são progressivamente reais, isto é, "minuto a minuto mais concretos". E, em havendo graus de concretude, desfaz-se a ideia de um absoluto. Tornam-se claras a percepção do tempo em andamento como certificador da paisagem, que é real porque permanece ou muda, e uma necessidade de confirmação constante do visto, de sua configuração móvel dentro do móvel temporal.

A referência ao aqui e agora, a seus limites concretos e suas probabilidades lógicas, encerra, por sua vez, uma desordem potencial desencadeada no plano da linguagem, onde se parece criar um duplo alucinante da paisagem regular, que ali, no entanto, permanece impávida, à revelia do que dela se diz ou escreve, como referência e provocação. O que temos, portanto, é a deflagração de um processo de percepção/construção gradual de realidade - e não da realidade - que se prolonga e alarga a partir de um ponto da paisagem que é sempre uma conexão aberta, um if, uma hipótese: e se houvesse uma pedra na cabeça da mulher? E se tivesse a casa realmente uma cabeça? E se pudesse andar um peixe na cabeça de um gato? E se pudesse um peixe andar? E se pudesse a mulher literalmente sentarse no tempo e na melancolia como se fossem banquetas de nos sentarmos nelas? "O imaginário", diz Helder, "sempre aberto e crescente, apodera-se de todas essas hipóteses reais e converte-as na muito astuta e operante realidade do imaginário". (HELDER, 1979, p. 23)

Afinal, por que esvaziar a poesia da poesia? Por que nos apararmos no mergulho? Sobre essa condição suspeita do texto, a realizar-se como um contínuo levantamento de possibilidades e suposições subversivas sobre a realidade dada, escreve Pedro Eiras: "o texto ainda não existe: deve ser construído a partir de uma panorâmica que se abre para o futuro, contornando o passado terrestre de tradições gastas" (EIRAS, 2005, p. 160). E chegaríamos a concluir: poderá existir a poesia, então, apenas como iminência, conjectura, numa espécie de paixão alucinada do poeta pela realidade dita concreta. Estamos falando da velha reverberação de ondas que uma pedra provoca ao ser jogada na superfície da água. A pedra - ou a paisagem - torna-se, neste momento, o start do mundo, ou de um mundo, com a qual o sujeito estabelece uma relação concêntrica. A noção de realidade, não obstante derivada do que os sentidos capturam, é, paradoxalmente, um desdobramento da imaginação deformadora. Esclarece 
Helder: "É nessa tensão real criada em escrita que a realidade se faz. O ofuscante poder da escrita é possuir uma capacidade de persuasão e violentação de que a coisa real se encontra subtraída. / O talento de saber tornar verdadeira a verdade." (HELDER, 1979, p. 56-57)

Tudo muito disciplinado, uma paisagem muito obediente, a não ser pelo fato de que as coisas estão seguras apenas no tempo, ancoradas no flagrante que a subjetividade faz desses momentos que passam. Mas será sobre essa fugacidade de um pensamento-olhar sobre um tempo-lugar que se erguerá a impressão de realidade concreta, aos poucos tornada certeza, ou abstração, ou eternidade: "Eternamente a mulher da mão passa a mão pelo gato abstrato". A consistência da realidade é a sua fragilidade. Enfim, o que temos é um lugar sempre atualizado, onde se prossegue a descrever, ou a performar, essencialmente, o ato da escrita. Assim sintetiza Guedes levando em consideração o universo poético helderiano:

Os aspectos de ucronia e utopia, conseguidos através da loucura sagrada, representam o lugar: lugar será a palavra que indica o acesso ao espaço e tempo outros, espaço e tempo da Poesia. Ou seja, o lugar funda a verdade poética, representando a assunção do conhecimento. (GUEDES, 1979, p. 49)

Tal concepção, entretanto, pode ser produtiva também para compreendermos a textualidade de Llansol. Têm eles em comum, acerca de suas escritas, esta noção de um lugar textual contínuo e sem fronteiras, de comunhão e mutação, portanto utópico, mantido pelo movimento constante do texto que se expande e se dobra, por meio de artifícios diversos. E, particularmente, concordam ambos que se trata de uma concepção, isto é, algo consciente e anunciado em suas obras. Não à toa Helder deu a um de seus últimos livros, editado em 2006, o título de Ou o Poema Contínuo, a dialogar dupla e explicitamente com o resto de sua obra. De modo semelhante, Llansol publica, em 2002, O Senhor de Herbais, com o subtítulo Breves ensaios literários sobre a reproducão estética do mundo e suas tentações, que retoma fragmentos e ideias de 11 livros anteriores seus, conforme precisou João Barrento (2003), aproveitando no texto e nas longas notas, nas quais o livro se desdobra - e que são o olhar do texto para o próprio texto - inúmeros temas e figuras já apresentados ao leitor. E antes, em 2000, já publicara Onde Vais, DramaPoesia?, cujo título, ao estabelecer uma interrogação inaugural, anuncia-nos, ao mesmo tempo, um caminho já começado, e incerto, um caminhante flagrado em seu percurso, e um vocativo pelo qual ele é nomeado e convocado, junto ao leitor e ao autor, a um diálogo, a um confronto.

Refiro-me, portanto, a comportamentos como esses, que revelam uma postura, uma compreensão desigual da relação entre a linguagem e a realidade. Relação esta que deve estar por trás de todo gesto de escrita para que ela se funde, nas palavras de Joaquim Manuel Magalhães, como uma "invenção autônoma” (MAGALHÃES, 1981, p. 124). E as invenções autônomas de Helder e Llansol fundam-se em uma sintaxe interrompida e de conexões semânticas inesperadas, ligando-os ao que a teoria literária já definiu como escrita ilegivel, resistência às convenções gramaticais e ideológicas, na trilha de Baudelaire, Rimbaud e Mallarmé, ou como escrita metassemiótica, que, na definição de Umberto Eco, é aquela que dificulta a leitura e resiste a ela, na medida em que propõe ao leitor o que ainda não foi explorado, ou disseminado, ou o que foi proibido pela cultura (ECO, 2001, p. 77-78). Filiam-se, por esse viés, à herança surrealista, 
legitimadora da espontaneidade, do inconsciente e da alucinação que, por vezes, parecem caracterizar os textos desses dois autores, na contramão do neorrealismo dos anos 60 em Portugal, quando ambos publicaram seus primeiros livros. Acercam-se, por fim, não se sabe bem se daquela loucura onírica ou da extrema lucidez em poesia.

O fato é que as poéticas de Herberto Helder e de Maria Gabriela Llansol são, hoje, na Literatura Portuguesa, talvez aquelas que mais radicalmente encarnam uma concepção do mundo e, por extensão, da literatura atravessada por essa tradição surrealista. Essas duas potências textuais prosseguiram suas trajetórias individuais de sucessivas publicações até agora, abrindo dois clarões no horizonte da literatura portuguesa dos últimos anos, ao mesmo tempo contrastando e contaminando sutilmente, com sua escrita híbrida e solar, a poesia dos mais jovens, dando novos sentidos ao generalizado "retorno ao real" e à suposta "rasura do sujeito" com que se costuma diagnosticar essa produção recente. Se nela geralmente assistimos à disseminação de uma ética muito mais fatalista, ou trágica, como na poesia do próprio Joaquim Manuel Magalhães, onde predomina uma temática de desencantamento, como "a ausência de uma moral, a pequenez, a degradação física, a velhice, o destruir da paisagem (a última das utopias), a falta de um espaço habitável, a morte e a devastação" (CRUZ, 2002, resumo), em Helder e Llansol, por outro lado, teremos uma escrita dramática sim, mas fulgurante, valorizadora da paisagem e regeneradora da utopia. Impressionam, portanto, pelo que suas obras significam em termos de resistência em pleno século XXI, mas não espanta, por outro lado, e pelo mesmo motivo, o de serem escritas que resistem, inclusive, à leitura, o fato de só nos últimos anos a crítica ter-lhes dado um espaço maior e mais refletido na academia.

A poética desses dois autores, identificadas agora num único singular para efeito desta proposta de reflexão, assenta-se sobre (1) uma conexão profunda entre os processos de leitura e escrita, geradora de uma tendência forte para a constante reescritura circular do texto, que se expande em dobraduras, em leituras e releituras de si mesmo; (2) uma visão utópica do texto como lugar de encontro da diferença e de reverberação dos afetos, o cenário ideal para o teatro do mundo, e (3) uma compreensão do sentido como metamorfose contínua, à semelhança do ciclo da vida: nascimento, reprodução, morte, nascimento... A princípio, tais pressupostos de enfrentamento do trágico da linguagem pelo exagero performático da própria linguagem não justificariam a excepcionalidade de suas obras, a não ser pelo fato de que acreditar nisso - numa visão da poesia como lugar de encantamento do mundo, de reavivamento das coisas ao redor, como formas da mesma energia que tudo perpassa e tudo irmana -, a não ser pelo fato de que acreditar numa poesia doadora da vida, na vida como circularidade e comunhão, e no poeta como sujeito consciente deste seu poder transformador, conforme vínhamos discutindo antes, leva-os a transgressões desiguais no cenário da literatura atual e, ao mesmo tempo, muito semelhantes entre si.

\section{3.}

Senão vejamos alguns excertos que podemos tomar como exemplos desta cosmovisão compartilhada, testemunhos de um lugar mágico, repleto de cenas (Llansol) e corpos (Helder) incandescentes, a compor o jogo de luz e sombra na paisagem super-povoada de seres e de encontros, a começar pelo encontro primordial entre o texto, verdadeiro ser em sua autonomia criadora, e o leitor, 
recriador convidado a penetrar nesse lugar de linguagem, e desafiado a mover-se nele. Começa assim Maria Gabriela a primeira página do seu Onde Vais, DramaPoesia?:

o que advém do texto é a construção da frase;

o que advém do espaço é o seu sentido;

o que advém da manhã é o sentimento de perca;

o que advém da noite é o recomeço da frase interrompida; assim cogitando caminhava

e abri a porta que dava para o teu rosto legente.

Não disse nada, a ouvir nos teus olhos

o som da rua que entrava pelas janelas.

Sentei-me nos lugares dispersos do teu silêncio, e esperei por ele _ uniu-se a mim como o oxigénio e o hidrogénio

se unem em forma de água,

numa união tão rara, imponderável e banal

como os nossos corpos unidos a ler

voltaremos à imagem da água.

Deixei de ouvir qualquer rumor e apaguei, sem poder dissolvê-la, a frase -

o indispensável caía no mesmo lugar do sentido; (LLANSOL, 2000, p. 11)

O que observamos aqui, de forma muito natural, é o fluxo verbal que desencadeia uma reflexão sobre aquilo de que se faz o sentido em literatura, aqui metonimicamente substituída pela expressão mais descompromissada "texto". O texto, anuncia o próprio texto, faz-se do que "advém do espaço", do que "advém da manhã", do que "advém da noite", ou seja, das ofertas arbitrárias dos dias indivisíveis, mas, sobretudo, do que advém do (próprio) texto. E é enquanto caminha e cogita (estas coisas) que o sujeito acompanha o texto, ou que o texto se faz, naturalmente. Isso não o impede de incluir nessa corrente aquilo que, de repente, parece desviá-lo de seu próprio fluxo de pensamento e observação da paisagem: a porta que se abre, que ele mesmo abre, e um rosto que surge em silêncio. Um silêncio que interrompe todo o rumor do texto, porque o flagra. Enfim, uma verdadeira aparição que vigia, julga e interroga. Assim, enquanto vai amalgamando todas as coisas que se imantam num único fluxo, supostamente tudo o que os olhos veem na paisagem da manhã ou da noite, paisagem contrária de si mesma: o sol? , os pássaros? , as árvores? , as estrelas? - não podemos saber - o texto prossegue, torna-se ele mesmo paisagem, retrato de um encontro, o ângulo de um olhar, e o que aparentemente o interrompe, outro olhar, promove, na verdade, "o recomeço da frase", e o texto novamente cresce porque foi surpreendido por uma figura ou um vivo que se destaca.

Llansol vincula, ainda, as noções de espaço e de tempo à construção do sentido no texto. Ela espacializa, por exemplo, o silêncio: "Sentei-me nos lugares dispersos do teu silêncio"; e os olhos, que se tornam lugares sonoros: "a ouvir 
nos teus olhos / o som da rua que entrava pelas janelas." Ela lança mão, também, de uma estratégia a que poderíamos chamar alquímica, muito próxima ao que encontramos na poesia de Herberto Helder, conforme identificou Maria Lucia Dal Farra (1986). Afinal, não se trata de uma união qualquer, mas de uma tão simples e, no entanto, tão vital como a união do oxigênio ao hidrogênio, a formar a água. Ora, quem abre a porta neste momento e, ao interromper pretensamente o pensamento do texto já começado, deixa revelar o seu rosto? Quem abre o livro, em sua primeira página, desejoso de compartilhar esse caminho? É, então, ao leitor que o texto se dirige, em diálogo dramático, a ele se une, como um paradoxo essencial: "numa união tão rara, imponderável e banal / como os nossos corpos unidos a ler", diz a voz do Texto, agora uma entidade assumida. Texto e Legente (como prefere Llansol), unidos como água, selam este pacto inicial que deverá perdurar durante toda a leitura.

Por fim, encerrando o fragmento, temos um novo e curto procedimento de espacialização, em que "o indispensável” e "o sentido" passam a ocupar o mesmo lugar. Como se trata de um texto mágico, ou poético, evidentemente não respeita uma das leis básicas da física, segundo a qual dois corpos não ocupam o mesmo lugar no espaço. Mas, de que lugar estamos falando? Um lugar de linguagem, lembremos. E, se "o indispensável caía no mesmo lugar do sentido", conforme anuncia o texto, como separá-los agora? Os mais atentos, porém, guardaram a pista inicial dada, obviamente, pelo próprio texto. Assim começa o nosso fragmento: "o que advém do texto é a construção da frase". E, daí em diante, o que assistimos é a uma sucessão de frases interrompidas, como uma perseverante tentativa de concluir o que, no último instante, finalmente se apaga: a frase. Testemunhamos um pensamento que segue circular e redundante, inicialmente por anáfora, que confessa um "sentimento de perca" e a necessidade de recomeçar a frase ("o recomeço da frase interrompida"), até o encontro fatal com o legente: a porta aberta, seu rosto a observar a labuta e o aparente fracasso do texto. E, de repente, o sentido que, antes, advinha do espaço, volta a ele, dissipado, perdido, apagado. Mas não para sempre, não verdadeiramente, porque fora já capturado pela frase, pressentido por ela, que, embora apagada, não fora dissolidida ("Deixei de ouvir qualquer rumor e apaguei, sem poder dissolvê-la, a frase"). A frase, onde todas as coisas podem estar ao mesmo tempo no mesmo lugar, igualmente indispensáveis, é capaz de remeter às suas próprias ausências, elipses, inversões, e nela o sentido permanece, mesmo quando interrompida ou depois de apagada a sua construção.

Trata-se, como podemos ver, de um verdadeiro estudo poético dos movimentos da criação, das potencialidades da sintaxe como organizadora do pensamento e propagadora do sentido que, no entanto, irá transcendê-la. Mas há outro exemplo em que, talvez, fique-nos mais clara a mistura de sensação e reflexão, de transparência e fluxo que define essa leitura livre e necessária como a água. No mesmo livro, um pouco mais adiante, Llansol escreve:

quando não existe nenhum ângulo de sombra e a palavra, por exemplo _ pomba _,

está a ser determinada em todos os sentidos, eu caminho na areia e ouvem-se ao longe, repercutindo uma infinitude de

sons naturais 
são sons verbais que dão propriedade ao areal à minha volta,

ou sou eu

e todas as areias e todas as formas ínfimas e preciosas de vida que

convergimos para eles e os cristalizamos num ar onde, nem que seja por instantes,

possamos comunicar.”(LLANSOL, 2000, p. 221)

Para Helder, o potencial unificador da poesia é o que lhe confere o seu caráter mágico. Em Llansol, por sua vez, esses encontros se dão, muitas vezes, como verdadeiros enigmas, ou, diria ela, "cenas fulgor", cuja revelação no texto desperta-nos para esse poder da linguagem que os dois fazem questão de pôr em prática. No exemplo acima, temos uma palavra-enigma: "pomba". É interessante observar que o próprio texto a isola entre travessões, como um aposto que nada explica, e que tampouco é decifrado. Sabemos apenas ser uma palavra que se impõe e se multiplica ("está a ser determinada em todos os sentidos"), ou "repercute", para aproveitar o verbo escolhido por Llansol. Repare que, desta vez, o enigma não interrompe o fluxo do texto, mas, ao contrário, o deflagra. O aparecimento da palavra "pomba" no percurso do texto anuncia uma nova equivalência, uma nova união, desta vez entre os "sons naturais" e os "sons verbais".

O texto quer nos dizer: não se trata de uma coisa ou outra, não é necessário fazer essa escolha. Ele é, paralelamente, uma coisa $e$ outra, "e todas as areias e todas as formas ínfimas e preciosas de vida que / convergimos para eles", os tais sons verbais/naturais, "e os cristalizamos num ar onde, / nem que seja por instantes, / possamos comunicar." Esse ar onde, naturalmente, é o texto que, ele sim, repercute todos os sons e sentidos que, dele, nos esforçarmos a ouvir, e dos quais desejamos obter a sintese moderna ou a unidade mística. $\mathrm{O}$ ar onde é o texto total, expressão que cunhei para me referir à ambição de totalidade e abrangência do mundo presente na textualidade llansoliana, e o texto total é o lugar da construção e da desconstrução do sentido, ao mesmo tempo que decifra seu próprio mistério, que olha para si mesmo a examinar sua própria estratégia: como converter uns seres noutros no seu espaço mágico e, assim, comunicar.

Em Um Falião no Punho - Diário 1, anterior a Onde Vais, Drama-Poesia, Llansol já apresentara a sua concepção de escrita ao desenvolver uma reflexão sobre o diário, suscitando, necessariamente, o questionamento das categorias de "tempo" e "espaço" que permeiam este gênero.

Tal como sou acompanhada pelos lagos _ as águas adormecidas naturais e duráveis _ de igual modo deve fazer parte da sombra,

que se desloca comigo,

inscrever os dias estendidos por longo período de tempo.

No seu calendário deve impôr-se imediatamente a noção de noite - uma semana, um mês, um ano de noites. Sem o calendário, o fluir do tempo deve parecer-lhe incomensurável, e tornar-se um obstáculo à separação 
clara entre as figuras que voltam em períodos (perigos) regulares, ao mesmo ponto da abóboda. (LLANSOL, 1985, p. 7)

Observe que, enquanto "escrever" sugere um registro, propósito tradicional do diário, Gabriela prefere, em vez disso, "inscrever", isto é, fazer uma marca, escrever dentro. Mas onde? A inscrita constitui uma marca dos (nos) dias, um fluxo a perseguir, a acompanhar outro. Tal como lidar com a água, inscrever os dias pressupõe saber cercar a sua fluidez, a sua falta de forma, dar-lhe limites, mesmo artificiais. A inscrita dos dias acompanha a sombra que acompanha o sujeito. E a sombra é a projeção do sujeito na paisagem, a sua marca movente, diríamos, que começa onde o corpo termina, sendo um seu prolongamento e o seu fim derradeiro. Sugestivo é pensar que duas sombras podem se tocar sem que os corpos efetivamente se esbarrem, e que, como sombra, dois corpos podem ser um só na paisagem. À sombra cabe a tarefa de reunir, na mesma extensão variável e contínua, o corpo do sujeito e o corpo dos dias que passam, dilatados, deformados como sombras perseguidas pelo corpo da linguagem. Por isso, não se pode escrever os dias nem as sombras. Apenas inscrevê-los, demarcando fronteiras, como lugares do calendário. Inscrever dias é recortar sombras que se expandem e desaparecem...

Tornar-se legente deste texto demanda, portanto, a superação das incoerências mais aparentes e a associação semântica e lexical em torno de pequenos núcleos transitórios que estão sempre atravessando categorias tradicionais de sentido (tempo, espaço, ler, escrever, eu, outro, natureza, criação, luz, sombra), e reiterando, de uma forma ou de outra, o que é a experiência da escrita para a autora.

\section{4.}

Agora voltaremos nossa atenção para a poesia de Herberto Helder, a identificar nela a mesma estrutura paisagística que observamos em Llansol. Se o sujeito olha a paisagem a partir de um ponto de vista, poderá haver um texto que inclua todos os pontos de vista? A julgar pela ambição de continuidade temporal e espacial revelada na obra dos dois autores, e pela semelhança entre seus procedimentos linguísticos, não seria equivocado pensar que essa é, de certa forma, uma utopia que eles compartilham. Se não a inclusão de todos os pontos de vista num único e grande texto, ao menos a posição do sujeito que deseja um encontro com todos eles. A mesma utopia que, em outros trabalhos, já chamei de texto total, referindo-me especificamente a Llansol, e que, para falar de Helder, preferi usar suas próprias palavras, caligrafia extrema. Tal utopia consiste em tratar o texto, ou o poema, como um lugar (ou um "acto") de comunhão mágica entre os elementos da realidade, partindo de uma concepção de linguagem que se apropria do erotismo das coisas constantemente em contato, afetando-se ${ }^{2}$ e transformando-se, trocando sua energia vital e criadora (SPINOZA, 1996).

Daí falarmos, ao mesmo tempo, do poema como corpo e do texto como lugar de encontros e acolhimento, espacializando-os, conferindo-lhes dimensões físicas (altura, largura, profundidade) imaginárias - e por isso mesmo eróticas que abrigariam esse fluxo de energia em trânsito, a que o sujeito, também imerso neste espaço, parece impor débeis fronteiras verbais (calendários, dias, sons que repercutem) e capturas efêmeras (frases interrompidas, palavras-enigmas). A espacialização da vida engendrada pela escrita atende, o mais naturalmente possível, e ainda assim de forma artificial, ao desejo de transpor fronteiras, ao desejo do reencontro, da identidade perdida, da comunhão. O espaço reorganizado 
subjetivamente pelo olhar do poeta encena paisagens cujos limites se querem fictícios ou provisórios, voláteis ou ilógicos, surpreendentemente habitados. Mas essas paisagens em que os corpos e as palavras se deslocam - e em que as metáforas, por outro lado, a tudo unificam - demarcam tão fortemente a existência de certos determinantes reais, fora do texto, duros e intransponíveis - limites ideológicos, políticos, culturais, econômicos -, quanto a vocação da linguagem para superálos. Mixando-os, sem perdê-los de vista (as correntes que ligam as palavras às coisas, de que falamos mais no início deste trabalho), no seu caldeirão poético transgressor, a linguagem onde tudo é espaço, ou onde para tudo há espaço, devolve-os, esses determinantes reais, e os limites que deles descendem, assim fragilizados, a outros olhares seduzidos pelo texto. Focalizemos um primeiro fragmento retirado do poema "Elegia múltipla":

Havia um homem que corria pelo orvalho dentro.

O orvalho da muita manhã.

Corria de noite, como em meio da alegria, pelo orvalho parado da noite.

Luzia no orvalho. Levava uma flecha pelo orvalho dentro, como se estivesse a ser caçado loucamente por um caçador de que nada se sabia.

E era pelo orvalho dentro.

Brilhava.

(HELDER apud GUEDES, 1979, p. 12-13)

Maria Estela Guedes fez, no seu livro sobre Herberto Helder já citado aqui, uma inteligente interpretação destes mesmos versos, que nos interessa recuperar em parte, justamente aquela que diz respeito à relação do sujeito poético com o espaço que o cerca. Helder põe-se a descrever uma cena de caça - das muitas cenas primitivas, assim como as de dança, que gosta de trazer para seus poemas - em que quase não nos restam dúvidas sobre o papel e o lugar de cada personagem. Guedes observa que se trata de uma

cena subaquática, também, com o homem perseguido reduzindo-se a proporções ínfimas para poder atravessar as gotas de orvalho; ou com o orvalho da muita manhã em volume bastante para permitir a completa imersão do corpo humano. (GUEDES, 1979, p. 13)

O poema joga, portanto, com os corpos, suas dimensões pequenas ou grandes, o espaço que ocupam ou disputam e sua capacidade de envolver ou adaptar-se a outro corpo com que manterão contato, modificando-o também. Embora a perseguição não ocorra efetivamente no mar, num rio ou lago, temos a predominância da água em torno deste corpo que brilha, um brilho próprio cuja incandescência - facilmente a podemos completar com nossa imaginação - é refletida, como toda luz o é, pelas gotículas d'água. Assim é que este "homem que corria pelo orvalho dentro" faz com ele uma comunhão de luz capaz de alterar a percepção que temos de sua luz própria, fundindo-se parcialmente com as gotas que, no entanto, não param de cair. Tampouco o homem para de correr. Uma cena verdadeiramente bela, mas cujo efeito de fotografia seria difícil de reproduzir até para os cineastas mais experientes. E conclui a autora: "Os dois 
corpos juntam-se - água e homem - e o seu brilho alaga o negro lençol da noite." (GUEDES, 1979, p. 13) Outro aspecto mencionado por Maria Estela Guedes a respeito do poema de Helder faz eco com a nossa leitura dos fragmentos de Llansol. Ela fala de uma

\begin{abstract}
"emoção que se espacializa - em meio da alegria - , tornando-se metáfora de orvalho: o homem move-se dentro da alegria como se move dentro do orvalho. Quer dizer que a luz vem de dentro do corpo, gerada pela alegria, e dá irradia para os elementos do cenário onde decorre a ação.” (GUEDES, 1979, p. 13)
\end{abstract}

Temos, então, que a alegria é um lugar onde nos podemos mover, um lugarágua, que nos envolve e onde, por menor que seja a gota, orvalho que era, podemos caber inteiramente. A alegria é o orvalho onde o homem perseguido se move e com que se funde, não obstante ela venha de dentro dele, como (a) luz. Mas está, ao mesmo tempo, do lado de fora, nas gotas que esqueceram de simplesmente molhar, para refletir. A alegria está dentro e fora, é a luz e o orvalho que a reflete, traspassa o homem e ilumina o orvalho em que ele, novamente, submerge iluminado. A alegria sai do homem e não sai. E assim, no texto mágico, a água conduz também uma outra espécie de eletricidade, igualmente capaz de converterse em movimento ("um homem que corria pelo orvalho dentro") e luz ("Luશia no orvalho", "Brilhara."), chamada alegria. Para finalizar, observemos, ainda, o segundo fragmento do poema: "O orvalho da muita manhã." Nele, o advérbio muita, sintaticamente ligado à palavra manhã, na verdade, intensifica o orvalho, garantindolhe o volume necessário para que o corpo do homem nele fique submerso. Jogo de inversão em que o autor, mais uma vez, confere ao tempo - a manhã, primeira parte do dia - caráter espacial: o volume do orvalho expande, por extensão, metonimicamente, o volume da manhã.

O que podemos confirmar desde aqui é que não só a emoção se espacializa, como muito apropriadamente escreveu Guedes, mas também o pensamento e o poema se espacializam. E, portanto, estão sujeitos à deformação em todas as suas dimensões. Isso equivaleria dizer, em larga medida, que tanto o pensamento quanto o poema ganham corpos que, por sua vez, ocupam espaços e neles se movimentam, sendo o próprio corpo um espaço a ser ocupado/tocado/atravessado por outros corpos, cujos limites e superfícies precariamente os vão distinguindo nesta interação. Tudo no texto é um lugar onde o sujeito está e onde encontra com outros, vivos e mortos, criaturas e criadores, sendo o próprio texto o Lugar por excelência. O outro também é um lugar onde o sujeito habita, um corpo do qual se alimenta, como o homem foi capaz de penetrar o espaço interno do orvalho com sua alegria, potencializando-a como luz na propriedade refletora da água. Só como lugares os seres podem experimentar o verdadeiro encontro que é a fusão, o afeto que é, ao fim e ao cabo, a metamorfose. Seja a metamorfose dos seres eles mesmos, seja a da própria língua, como bem assinala Izabela Leal em recente artigo sobre a conflituosa relação, na escrita de Herberto Helder, do "idioma poético" que se esforça por criar-se contra a tradição da "língua materna". A certa altura de suas considerações sobre o ferino embate matricida que marca, simultaneamente por ruptura e reafirmação, a recriação da língua portuguesa na poesia e, por meio desta, a necessária reescritura da própria nação portuguesa, Leal afirma o seguinte: 
se estamos associando o filho à criação de um idioma poético novo, a mãe será não apenas a "fonte" desse idioma, como também, e necessariamente, aquilo que se produz a partir dele. Pois não podemos dizer que, em última análise, o que a fala poética faz é consagrar a língua mãe, ainda que isso ocorra através da sua parcial destruição? (LEAL, 2008, p. 131)

Tem-se, aí, a base metamórfica fulcral sobre a qual se assentarão quaisquer propostas futuras de apropriação de um corpo pelo outro, de um espaço pelo outro, de uma tradição pela outra. A linguagem permite ao sujeito (re)criar este mundo de espaços comunicantes e interseccionáveis onde habitar e mover(-se) é ser, onde transformar(-se) é reformular e reconhecer, mas sobretudo comunicar, e onde ser e comunicar é, novamente, criar espaços e (re)ligá-los. Mais adiante, Leal completa: "Mesmo que o matricídio ocorra, o reino do literário continua a ser o lugar em que mãe e filho coexistem, enfrentam-se e reinventam-se." (LEAL, 2008, p. 132)

De volta ao tema da paisagem, eis a mais simples de suas utopias: a preservação renovada na interligação dos espaços. A sua complexidade corre por conta das articulações que cada autor, Herberto Helder e Maria Gabriela Llansol, fará para concretizar essas ideias, ou princípios ideológicos, ou, em outras palavras, essa sua ética no texto. A partir destas conclusões, torna-se fácil entender por que a metáfora do lugar é uma das chaves para compreender essas duas obras. A seguir, reproduzo um poema completo de Helder, cujas partes sublinhadas por mim comentarei mais rapidamente, procurando sempre uma coerência com as constatações que já apresentei até agora. Trata-se do texto 3 de Antropofagias:
Afinal a ideia é sempre a mesma o bailarino a pôr o pé no sítio uma coisa muito forte
na cabeça no coração nos intestinos no nosso próprio pé pode imaginar-se a ventania quer dizer
«o que acontece ao an» é a dança
pois vejam o que está a fazer o bailarino que desata por aí fora (por «aí dentro» seria melhor) ele varre o espaço
se me permitem varre-o com muita evidência somos obrigados a «ver isso»[1]
que faz o pé forte no sítio forte o pé leve no sítio leve o sítio rítmico no pé rítmico?
e digo assim porque se trata do princípio «de cima para baixo de baixo para cima»
que faz? que fazem? oh apenas um pouco de geometria em termos de tempo um pouco de velocidade em termos de espaço dentro de tempo «vamos lá encher o tempo com rapidez de espaço»[2] pensam os pés dele quando o ar está pronto o «problema» do bailarino é coisa que não interessa por aí além mas são chegados os tempos da agonia estamos «exaltados» com este pensamento de morte é preciso pensar no «ritmo» é uma das nossas congeminações exaltadas 
na realidade algo se transformou desde que ele começou a dançar[3]

sem qualquer auxílio excepto

não haver ainda nomes para «isso» e haver os ingredientes

do espectáculo i. e. a qualidade «forte» do sítio

e pés

esperem pela abertura de negociações entre «não» e «sim»

hão-de ver como coisas dessas se passam

não vai ser fácil os recursos de designação as acomodações

várias

já se não encontram às ordens de vossências

comecem a aperceber-se da «energia» como «instrumento»

de criar «situações cheias de novidade»

vai haver muito nevoeiro nessas cabeças

e ainda «O coração caiu-lhe aos pés» o banal

a contas com o inesperado talvez então se tenha a ideia de murmurar

«Os pés subiram-lhe ao coração»

pois vão dizendo que exagero logo se verá[4]

também Jorge Luis Borges escreveu esta coisa um nadinha espantosa

«a lua da qual tinha caído um leão» nunca se pode saber

maçãs caem Newton cai na armadilha

quedas não faltam umas por causa das outras

os impérios caem etc. o assunto do bailarino cai

mas sempre em cima da cabeça e estamos para ver

Cristo a andar sobre as águas é ainda o caso do bailarino

«O estilo»

claro que «isto» apavora

a dança faz parte do medo se assim me posso exprimir

(HELDER, 2004, p. 278-279)

No poema de Helder, as linhas sublinhadas e os trechos numerados são interferências minhas. De modo que, no trecho 1, que vai do primeiro ao nono verso, percebemos, mais uma vez, a conexão ou fusão corpo-natureza como pressuposto para a criação estética (dança, poesia), já que "por aí fora” equivale a "por aí dentro". Na dança descrita pelo texto, como ritual primitivo, assim como a caça que vimos antes, outra vez o corpo (cabeça, coração, intestinos, pé) e elementos da paisagem natural (sítio $=$ solo, espaço, ventania) são redefinidos reciprocamente. Lembremos que esta reciprocidade é também um princípio essencial da filosofia spinosista acatada por Llansol. Tanto para ela quanto para o nosso poeta, a criação estética é um procedimento de redefinição recíproca, contínua, consciente e ética do homem e da natureza, do sujeito e da paisagem, de encontro constante de novos sentidos, valorizando essa mútua vulnerabilidade e, consequentemente, desejando sua preservação. Tal compreensão tem um vínculo não muito distante, portanto, com os valores ecológicos que, só a partir do final do século XX, tentamos incutir nas novas gerações. Ela nasce, porém, não de uma ameaça biológica ou climática, mas de uma sensibilização erótica verdadeira e original com o que viemos até aqui chamando de paisagem, a qual leva, por sua vez, a uma ética também verdadeira. 
No trecho 2 do poema, que vai do décimo ao décimo sétimo verso, a criação (dança) é a oportunidade de interferir nos elementos da paisagem. Dessa interferência são geradas novas configurações e relações entre o sujeito e esses elementos: a força ou a leveza, o ritmo, a direção do movimento, a velocidade. Já no trecho 3, do décimo oitavo ao vigésimo terceiro verso, temos uma relação profunda entre a consciência sensível do corpo e a consciência ética do pensamento. O fascínio da subjetividade com a paisagem, como se vê, é o primeiro pré-requisito para a rediscussão dos velhos valores humanistas e para a construção de uma nova ética necessária à sobrevivência, questões que não se separam de uma reflexão sobre a própria criação poética: "pensam os pés dele quando o ar está pronto / o 'problema' do bailarino é coisa que não interessa por aí além / mas são chegados os tempos da agonia / estamos 'exaltados' com este pensamento de morte / é preciso pensar no «ritmo» é uma das nossas congeminações exaltadas” (grifos meus).

Por fim, no trecho 4, que vai do vigésimo quarto ao trigésimo oitavo verso, otimismo e esperança. O eu poético crê que "na realidade algo se transformou desde que ele começou a dançar". Mesmo em "não haver ainda nomes para 'isso", e justamente por isso pensamos e tentamos a melhor forma de dizer, por isso fazem-se poemas, por isso existem poetas. Vejamos, agora, um excerto do fragmento IV de Do Mundo:

Se se pudesse, se um insecto exímio pudesse, com o seu nome do princípio, entrar numa turquesa, monstruosa pela amplitude da cor e do exemplo, se até ao coração da pedra e dele mesmo devorasse a matéria exaltada, por si e por ela e pelo nome primeiro ficaria vivo: profundamente num único nó de corpo, e brilharia até se consumir de si, todo _ e a terra, suportaria ela o poema disso?

(HELDER, 2000, p. 142)

O inseto funde-se com a pedra.O "nó de corpo" formado pelos corpos do inseto e da pedra é a alegoria de um encontro que ganha dimensões infinitas. Uma transformação, uma fusão alquímica de substâncias, diria Maria Lúcia Dal Farra. Ou de vivos, diria Llansol. As implicações não são menores do que a morte e a vida, temáticas reincidentes em Herberto Helder e Maria Gabriela Llansol. De novo, o poema é um ato ou uma intervenção, ou ainda um lugar de coesão, de metamorfose, um acontecimento mágico, um nó, uma cena-fulgor.

\section{5.}

Operar a mutação é um procedimento que se evidencia na escrita, em Helder, e a antecede, em Llansol, na leitura do fluxo contínuo que sua escrita pretende acompanhar. É a deformação do corpo da linguagem, suas conexões semânticas e sintáticas imprevistas, suas interrupções e conversões abruptas, são esses recursos tão semelhantes que aproximam os dois de um campo magnético comum, necessário (1) à ordenação do caos pelo estilo, desejo do poeta - "estilo é um modo sutil de transferir a confusão e violência da vida para o plano mental de 
uma unidade de significação.” ( HELDER, 2005, p. 11) -, ou (2) à rendição afetiva à diversidade da vida - "o encontro inesperado do diverso" (LLANSOL, 1994, p. 6.) pela leitura-escrita incessante do mundo, poética de Llansol. Tanto em um quanto no outro, verifica-se uma confiança, e por que não, uma religiosidade da linguagem, onde seriam possíveis todas as transformações e encontros.

Retomando Magalhães, aqui não são mais as referências ou filiações ideológicas que importam, senão a habilidade do corpo da linguagem de encarnar qualquer ideologia da cultura. Encarnar é diferente de parafrasear. Isso é difícil, uma linguagem não reprodutora, não redundante. Assim, o que chamo de caligrafia extrema nestes autores é, como tentei demonstrar, o lugar de linguagem criado por eles para o encontro e a transfiguração, motores de suas poéticas. Seus versos ou sua prosa inclassificável são flutuações do mesmo impulso de conexão com tudo que vive, abrem-se sempre como espaços utópicos (um paradoxo?) assegurados não por limites evidentes, ou convenientes, sequer por uma clara fronteira com o real, mas espaços definidos por uma presença constante e obsessiva que a tudo inclui e subverte ao seu deserto normativo: a presença móvel da linguagem, sempre a atualizar outras presenças, a encenar outras figuras. Ao promoverem a metamorfose e a integração com a alteridade, via citação e metáfora, suas poéticas lançam uma carga de otimismo, uma perspectiva positiva do trabalho poético sobre a tendência cética da poesia portuguesa contemporânea, assumida no próprio corpo do texto. E, sinceramente, essa é a razão principal de minha identificação com suas obras.

Talvez esse lugar mágico de linguagem diga-nos mais sobre um novo tipo de humanismo, novo porque encarnado, do que sobre velhos discursos, embora também os retome como questionamento e referência. Um humanismo não antropocêntrico, tampouco apenas naturalista, mas que tem no homem, ainda, a oferta de um vínculo: paisagens ao mesmo tempo coletivas e particulares, congregações sutis. Um humanismo que parte da criação, dom assumido tanto por Helder quanto por Llansol, rumo a uma ética cujos princípios instalam-se no corpo mesmo do discurso, e não apenas como referências exteriores, a redefinir os caminhos políticos desse discurso, o caminho da poesia, o caminho da literatura, inseparável de nossas escolhas estéticas. 


\section{NOTAS}

1. Uma versão preliminar deste artigo, sob o título "Helder e Llansol: caligrafias extremas", foi publicada nos Anais do XXII Congresso Internacional da Associação Brasileira de Professores de Literatura Portuguesa - Memória, Trânsitos, Convergências, realizado na cidade de Salvador, na Bahia, em setembro de 2009.

2. É na filosofia seiscentista de Spinosa que Llansol buscará uma de suas maiores inspirações, transformando seu próprio texto numa concretização sempre atualizada do conceito de afeto demonstrado geometricamente pelo filósofo. Simplificadamente, segundo ele, todos os seres se afetam, direta ou indiretamente (via pensamento, mesmo na distância temporal ou espacial), e se transformam, determinando o aumento ou a diminuição do que ele chama de potência de viver/existir de cada um.

\section{REFERÊNCIAS BIBLIOGRÁFICAS}

BARRENTO, João. O ressalto de uma frase. In: Jornal Público (Mil Folhas), 15/02/ 2003.

COLLOT, Michel. A teoria da paisagem. In: ROGER, Alain (dir.). La théorie du paysagem en France (1974-1994). Syssel: Cham Vallon, 1995.

CRUZ, Paula Cristina Oliveira da. Restos: o exercício crítico e poético de Joaquim Manuel Magalhães. Dissertação de Mestrado, Universidade do Minho, 2002.

DAL FARRA, Maria Lucia. A Alquimia da Linguagem. Leitura da cosmogonia poética de Herberto Helder. Lisboa: Imprensa Nacional (Casa da Moeda), 1986.

ECO, Umberto. As formas do conteúdo. São Paulo: Perspectiva, 2001.

EIRAS, Pedro. Scherzo com helicópteros: a metáfora do voo em Herberto Helder. In: Rerista da Faculdade de Letras — Linguas e Literaturas, II Série, vol. XXII. Porto: 2005, p. 151-184.

GUEDES, Maria Estela. Herberto Helder poeta obscuro. Lisboa: Margens do Texto, 1979.

HELDER, Herberto. Photomaton e V Vox. Lisboa: Assírio e Alvim, 1979.

. Ou o poema contínuo. Lisboa: Assírio \& Alvim, 2004.

Os Passos em Volta. Rio de Janeiro: Azougue Editorial, 2005.

LEAL, Izabela. No reino das mães: notas sobre a poética de Herberto Helder. In: Cadernos de Letras da UFF - Dossiê: Literatura, língua e identidade, n. 34. Niterói: 2008, p. 127-138.

LLANSOL, Maria Gabriela. Um falião no punho - Diário 1. Lisboa: Rolim, 1985. . Lisboaleiprig 1 - O Encontro Inesperado do Diverso. Lisboa: Rolim, 1994. . Onde Vais, Drama-Poesia. Lisboa: Relógio d'Água, 2000.

MAGALHÃES, Joaquim Manuel. Os Dois Crepúsculos. Sobre Poesia Actual e Outras Crônicas. Lisboa: A Regra do Jogo, 1981 